\title{
Verkferlar í tengslum við fæðuofnæmi og fæðuópol í leikskólum Reykjavíkurborgar
}

\author{
Aðalheiður Rán Prastardóttir ${ }^{1}$ lýðheilsufræðingur, Fríða Rún Pórðardóttir² næringarráðgjafi og næringarfræðingur, \\ Jóhanna Torfadóttir ${ }^{1,3}$ næringar- og lýð̌heilsufræðingur
}

\section{Á G R I P}

Inngangur: Markmið rannsóknarinnar var að kanna algengi fæðuofnæmis og fæðuópols hjá börnum á leikskólum Reykjavíkurborgar og hversu vel leikskólar standa að pví að hafa umhverfi barna með fæðuofnæmi sem öruggast.

Efniviður og aðferðir: Spurningalisti útbúinn fyrir pessa rannsókn var sendur til 65 leikskóla Reykjavíkurborgar árið 2014. Svör fengust frá 49 leikskólum (75\%) með 4225 börn. Algengi fæðuofnæmis og fæðuópols var metið út frá fjölda læknisvottorða sem afhent voru til leikskólanna. Lýsandi tölfræði var notuð til að meta hvort ferlar væru til staðar fyrir börn með fæðuofnæmi/-ópol á leikskólum og hvort peir tengdust menntun leikskólastjóra, menntun starfsmanns í eldhúsi og fjölda barna á leikskólanum.

Niðurstöður: Algengi fæðuofnæmis og fæðuópols var 5\%, bráðaofnæmis
$1 \%$ og fjölfæðuofnæmis $1 \%$ samkvæmt læknisvottorðum. Mjólkurópol var algengast (2\%) en par næst mjólkurofnæmi (2\%) og eggjaofnæmi (1\%). Allir leikskólar nema einn voru með börn með fæðuofnæmi og/eða -ópol. Tæpur helmingur leikskólanna (41\%) var með viðbragðsáætlun til að fara eftir ef barn skyldi fyrir slysni fá ofnæmisvaka með fæðunni. Aðeins $55 \%$ leikskóla með barn með bráðaofnæmi sögðu allt starfsfólk sitt pekkja einkenni ofnæmiskasts og aðeins $64 \%$ peirra sögðu starfsfólk sitt upplýst og pjálfað í viðbrögðum við ofnæmiskasti. Engin marktæk tengsl voru á milli menntunar leikskólastjóra, starfsmanns í eldhúsi og fjölda barna á leikskóla og hvernig staðið var að málum barna með fæðuofnæmi/-ópol. Ályktun: Fimm prósent leikskólabarna í rannsókninni voru með fæðuofnæmi og/eða fæðuópol í Reykjavík. Í 59\% leikskóla skorti viðbragðsáætlun í tengslum við fæðuofnæmi.

\section{Inngangur}

Algengi fæðuofnæmis hjá evrópskum börnum á aldrinum 0-18 ára spannar allt frá 2-28\% á árunum 2003-2005. ${ }^{1-3}$ Munur á aðferðum rannsakenda við upplýsingaöflun á hvort fæðuofnæmi sé til staðar er mikill. Í sumum tilvikum er algengi fæðuofnæmis byggt á frásögn foreldra en í öðrum tilvikum á húðprófi, blóðprófi og/ eða tvíblindum polprófum. ${ }^{3-5}$ Íslensk rannsókn á 0-1 árs börnum staðfesti fæðuofnæmi hjá 1,9\% íslenskra barna með tvíblindu polprófi (IgE-miðlað fæðuofnæmi) en rannsóknin var gerð á árunum 2005 til 2008. ${ }^{6}$ Til samanburðar sýndi dönsk rannsókn á priggja ára börnum fyrir aldamótin að 3,4\% barna voru með fæðuofnæmi en algengið lækkaði í 1,2\% við 6 ára aldurinn, greint með tvíblindu polprófi. ${ }^{7}$

Pegar einstaklingar eru með ofnæmi fyrir tveimur eða fleiri fæðutegundum kallast pað fjölfæðuofnæmi (multiple food allergy). Í danskri rannsókn par sem börnum var fylgt eftir frá fæðingu til 6 ára aldurs greindust 3,7\% barna með fjölfæðuofnæmi greint með polprófi. ${ }^{8}$ Í daglegu tali eru peir sem eiga á hættu að fá ofnæmislost sagðir vera með bráðaofnæmi. Helsta ástæða ofnæmislosts (anaphylaxis) er neysla fæðutegundar (33\%). ${ }^{9}$ Hjá börnum má

${ }^{1}$ Miðstöð i lýðheilsuvísindum Háskóla Íslands, ${ }^{2}$ Landspítala, ${ }^{3}$ Háskóla Íslands.

Fyrirspurnum svarar Jóhanna Torfadóttir, jet@hi.is

https://doi.org/10.17992//bl.2018.01.168

Greinin barst til blađsins 16. júní 2017, sampykkt til birtingar 3. desember 2017. einnig rekja meirihluta tilfella (56-84\%) ofnæmislosts til fæðuofnæmis. ${ }^{10-12}$ Áströlsk rannsókn sem skoðaði innkomur á bráðamóttöku barna vegna ofnæmislosts greindi frá pví að flest tilvik (48\%) verða á heimili barnsins en næst algengasti staðurinn er skólinn og daggæslan (9\%). ${ }^{13}$ Ofnæmislost geta verið banvæn en pað er sjaldgæft. ${ }^{10,13}$ Pað er pví nauðsynlegt að gerð sé viðbragðsáætlun um hvernig bregðast skuli við ofnæmiskasti barns hjá aðilum/ stofnunum sem bera ábyrgð á börnum á dagvinnutíma. ${ }^{14}$

Pegar fjallað er um fæðuópol á pað oftast við um mjólkurópol og glútenópol. Mjólkurópol stafar af pví að einstaklingur getur ekki brotið niður mjólkursykur í meltingakerfinu ${ }^{15}$ en glútenópol er sjálfsofnæmissjúkdómur. ${ }^{16}$

Í rannsókn sem meðal annars var gerð á Íslandi kom fram að starfsfólk grunnskóla í Reykjavík er almennt meðvitaðra um fæðuofnæmi en starfsfólk skóla hinna landanna 7 sem tóku pátt í rannsókninni. Pannig greindu 85\% íslensku skólanna (n=11) frá pví að starfsfólk sitt væri frætt um einkenni fæðuofnæmis. Einnig höfðu 44\% (n=4) grunnskólanna frætt starfsfólk sitt um hvernig ætti að lesa innihaldslýsingar og 91\% skólanna $(n=10)$ voru með adrenalínpenna á staðnum. Aðgerðaráætlun við alvarlegu ofnæmisviðbragði í skólum var til staðar í 67\% tilvika $(n=8)$ par sem gert er ráð fyrir að starfsmaður geti notað adrenalínpenna. Stjórnendur fjögurra skóla vildu hins vegar að annaðhvort væri hringt í foreldrana eða á sjúkrabíl í stað pess að nota adrenalínpenna. ${ }^{17}$ 
Tafla I. Upplýsingar um fæðuofnæmi og fæðuópol á leikskólum Reykjavíkurborgar, sumar og haust 2014.

\begin{tabular}{lcc}
\hline & Fjöldi & (\%) \\
\hline Fjöldi leikskóla & 49 & \\
\hline Leikskólar með barn/börn með fæðuofnæmi/-ópol & 48 & 98 \\
\hline Leikskólar með barn/börn með bráðaofnæmi & 22 & 45 \\
\hline Leikskólar með barn/börn með fjölfæðuofnæmi & 26 & 53 \\
\hline Fjöldi barna & 4225 & \\
\hline Börn með fæðuofnæmi/-ópol & 213 & 5 \\
\hline Börn með bráðafæðuofnæmi & 41 & 1 \\
\hline Börn með fjölfæðuofnæmi & 47 & 1
\end{tabular}

Aðeins börn með læknisvottorð voru skilgreind með ofnæmi/ópol og bráđaofnæmi í rannsókninni.

Höfundar vita ekki til pess að rannsóknir hafi verið gerðar á Íslandi sem sýna hvernig staðið er að málefnum barna með fæðuofnæmi/-ópol innan leikskóla.

Markmið pessarar rannsóknar var að kanna algengi fæðuofnæmis og fæðuópols hjá börnum í leikskólum Reykjavíkur. Einnig var markmið rannsóknarinnar að kanna hversu vel leikskólar tryggja að umhverfi barna með fæðuofnæmi og/eða -ópol sé öruggt. Að lokum var kannað hvort innri pættir leikskólans hefðu áhrif á öryggi barna með fæðuofnæmi, svo sem menntun leikskólastjóra, starfsmanns í eldhúsi og fjöldi barna á leikskólanum.

\section{Efniviður og aðferðir}

Rannsóknin var lýsandi pversniðsrannsókn, framkvæmd á tímabilinu júní til september árið 2014. Hún var sampykkt af vísindasiðanefnd Íslands (VSNb2014050004/03.07.) og tilkynnt til Persónuverndar.

Spurningalisti var settur upp á vefsíðunni Questionpro.com og sendur rafrænt á alla leikskólastjóra hjá leikskólum Reykjavíkurborgar að sjálfstætt starfandi leikskólum undanskildum, eða til alls 65 leikskóla. Samkvæmt opinberum gögnum voru 6003 börn í leikskólum Reykjavíkurborgar í október 2014. Af pessum 65 leikskólum sem fengu sendan spurningalistann svöruðu 49 leikskólastjórnendur með alls 4225 börn (75\% svarhlutfall).

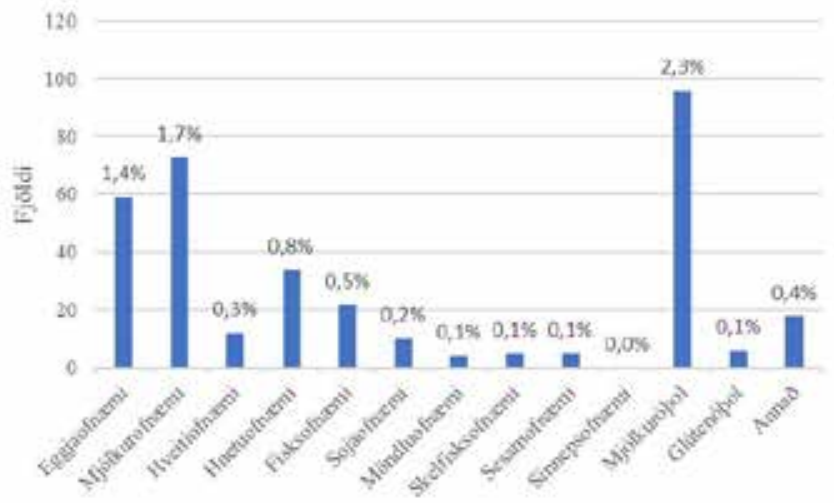

Mynd 1. Fæðutegundir sem valda ofnæmi og ópoli meðal 2-6 ára barna á leikskólum Reykjavíkurborgar, sumar og haustið 2014.
Tafla II. Svör við spurningum um hvort viðbragðsáætlun (virkt ferli) sé til staðar sem fer i gang ef barn með fæðuofnæmi eða fæðuóbol fær mat með ofnæmisvaka og hvort starfsmenn i leikskólum séu upplýstir og pjálfaðir í að bregðast við ofnæmiskasti. (\%)

\begin{tabular}{lll}
\hline & Já & Nei \\
\hline Viðbragðsáætlun & $20(41)$ & $29(59)$ \\
\hline Upplýstir og pjálfaðir & $30(61)$ & $19(39)$ \\
\hline
\end{tabular}

Valið var að senda á leikskóla Reykjavíkurborgar pví par er pess krafist að foreldrar/forráðamenn skili læknisvottorði ef gefa parf börnum sérfæði vegna fæðuofnæmis og/eða fæðuópols. ${ }^{18}$

\section{Mæliaðferðir}

Spurningalistinn samanstóð af 40 spurningum. Hann var gerður sérstaklega fyrir pessa rannsókn í samvinnu við Astma- og ofnæmisfélag Íslands, nánar tiltekið Fríðu Rún Pórðardóttur næringarfræðing og formann félagsins. Ekki var hægt að rekja svör spurninga til ákveðins leikskóla eða barna.

Spurningalistinn var sendur út ásamt kynningarbréfi á netföng leikskólastjóra par sem hlekkur var gefinn á rannsóknina á vefsíðu QuestionPro.

Listinn var forprófaður tvisvar, annars vegar á leikskóla par sem vitað var að starfsfólk pekkti vel til fæðuofnæmis og hins vegar á leikskóla par sem ekki var vitað til að pekking væri til staðar um fæðuofnæmi og fæðuópol.

\section{Mat á ofnæmi og ópoli leikskólabarna}

Spurt var um fjölda barna með læknisvottorð vegna fæðuofnæmis/-ópols á núverandi skólaári í spurningalistanum. Til að meta algengi fæðuofnæmis/-ópols var fjölda barna með læknisvottorð deilt með fjölda allra barna á leikskólunum sem tóku pátt í könnuninni. Einnig var spurt hvort börn væru annars vegar með læknisvottorð vegna bráðaofnæmis og hins vegar vegna fjölfæðuofnæmis. Að lokum var hægt að haka við um hvers konar ofnæmi eða ópol var að ræða. Valmöguleikarnir voru: ofnæmi fyrir eggjum, mjólk, hveiti, hnetum, fiski, soja, möndlum, skelfiski, sesam og sinnepi. Einnig var hægt að haka við mjólkurópol og glútenópol.

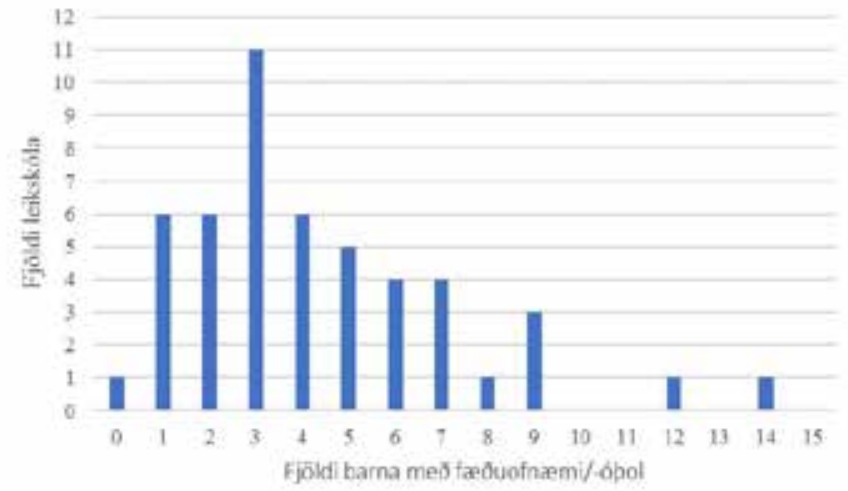

Mynd 2. Fjöldi leikskóla með eitt eða fleiri börn með fæðuofnæmi/-ópol. 
Tafla III. Samband milli menntunar stjórnenda og hvort viðbragðsáætlun er til staðar í leikskólum ef matur inniheldur ofnæmis- eða ópolsefni.

\begin{tabular}{lccc} 
& N & Já (\%) & OR \\
\hline Menntun leikskólastjóra & & & \\
\hline Grunnmenntun & 18 & $8(44)$ & - \\
\hline Viðbótardiplóma & 20 & $8(40)$ & $0,83(0,23-3,03)$ \\
\hline Framhaldsmenntun & 11 & $4(36)$ & $0,71(0,15-3,33)$ \\
\hline Menntun starfsmanns í eldhúsi & & & $0,54(0,10-2,80)$ \\
\hline Ómenntaður & 18 & $7(39)$ & - \\
\hline Menntaður & 30 & $13(43)$ & $1,20(0,37-3,96)$ \\
\hline
\end{tabular}

${ }^{1}$ Leiđrétt fyrir fjölda barna á leikskóla og fjölda starfsfólks á leikskóla. OR = Odds ratio = gagnlíkindahlutfall.

Viðbragðsáætlun fyrir börn með fæðuofnæmi og/eða -ópol

Sérstaklega var unnið með prjár spurningar úr spurningalistanum sem póttu lýsa vel hvernig unnið var að fæðutengdum málum barna með fæðuofnæmi/-ópol innan leikskólans:

1. Er til staðar viðbragðsáætlun sem fer í gang ef barn með fæðuofnæmi/-ópol fær mat með ofnæmisvaka í? Pessi spurning verður hér eftir kölluð viðbragðsáxtlun.

2. Eru allir starfsmenn leikskólans upplýstir og pjálfaðir í pví hvernig bregðast skal við ofnæmiskasti barns? Pessi spurning verður hér eftir kölluð upplýstir og pjálfaðir.

3. Pekkja allir starfsmenn leikskólans einkenni ofnæmiskasts barns?

Spurningarnar höfðu prjá svarmöguleika: 1) já, 2) nei og 3) á ekki við. Við úrvinnslu gagna var svarmöguleiki nr. 3 settur saman við svarmöguleika nr. 2 sem var nei.

\section{Skýribreytur}

Leikskólastjórnendur voru beðnir um að haka við hæsta menntunarstig sem lokið var og voru valmöguleikarnir eftirfarandi: 1) próf úr Fóstruskólanum, 2) B.Ed., 3) önnur grunnmenntun, 4) viðbótardiplóma, 5) M.Ed., 6) önnur framhaldsmenntun, 7) Ph.D., 8) Ed.D. og 9) önnur menntun. Menntuninni var skipt í prjá flokka: grunnmenntun, viðbótardiplóma og framhaldsmenntun. Pátttakendur með grunnmenntun voru allir sem höfðu lokið 1) prófi úr Fóstruskólanum, 2) B.Ed. og 3) annarri grunnmenntun. Pátttakendur með viðbótardiplóma voru peir sem hökuðu við valmöguleika 4) viðbótardiplóma. Pátttakendur með framhaldsmenntun voru peir sem höfðu lokið við 5) M.Ed. og 6) annarri framhaldsmenntun. Enginn leikskólastjórnendanna hafði lokið Ph.D. eða Ed.D. Prír hökuðu við 9) önnur menntun en við pann valmöguleika var opið svar og var hægt að færa pau svör á viðeigandi stað í prískiptri menntunarbreytunni sem er lýst hér að ofan.

Til að kanna menntunarstig starfsmanns í eldhúsi/mötuneyti var spurt: Er starfandi menntaður matartæknir, matreiðslumaður eða matráður við leikskólann? Svarmöguleikarnir voru 1) já, 2) nei og 3) önnur menntun starfsmanns í eldhúsi/móttökueldhúsi. Breytan var endurskráð í tvíkosta flokkabreytu en í premur tilvikum var starfsmaður í eldhúsi skráður pannig að hann væri kominn áleiðis í matartækninámi og voru peir endurskráðir pannig að peir væru með enga menntun.

Einn leikskóli keypti mat annars staðar frá og var hann undanskilinn í greiningu gagna pegar metið var hvort menntun starfs- manns í eldhúsi væri tengt pví hvort viðbragðsáætlun væri til staðar og hvort starfsfólk væri upplýst og pjálfað til að bregðast við ofnæmiskasti barns.

Stærð leikskóla var annars vegar metin eftir fjölda barna og hins vegar eftir fjölda starfsfólks. Fjölda barna á leikskóla var skipt í minni leikskóla (47-83 börn) og stærri leikskóla (84-172 börn), var skipting gerð pannig að sem líkastur fjöldi væri í báðum hópum. Fjöldi starfsfólks á leikskóla var skipt í minni leikskóla (12-21 starfsmaður) og stærri leikskóla (22-42 starfsmenn).

Í tveimur tilvikum hafði verið sleginn inn rangur fjöldi barna á leikskóla, annars vegar 0,3 börn og hins vegar 3 börn. Meðaltal var tekið af fjölda barna í leikskólunum sem tóku pátt í rannsókninni ( $\mathrm{N}=86)$ og sú tala notuð fyrir pessa tvo leikskóla. Einn leikskóli misskráði fjölda starfsmanna pannig að einn starfsmaður ynni á leikskólanum en meðalfjöldi starfsmanna í hinum leikskólunum sem tóku pátt voru 24 starfsmenn og var sú tala notuð fyrir pennan leikskóla.

\section{Úrvinnsla gagna}

Stuðst var við forritið SPSS útgáfu 23 við tölfræðilegar greiningar. Notuð var lýsandi tölfræði til að meta algengi fæðuofnæmis og fæðuópols. Fjöldi barna með fæðuofnæmi og fæðuópol var metinn út frá fjölda læknisvottorða.

Einnig var pví lýst hvaða fæðutegundir voru helst að valda fæðuofnæmi/-ópoli og hvort um fjölfæðu- eða bráðaofnæmi væri аð ræðа.

Spurningalistanum lauk með opnum athugasemdum sem dregnar voru saman og fjallað um í niðurstöðukaflanum.

Gerð var tvíkosta lógistísk aðhvarfsgreining til að meta gagnlíkindahlutfall (OR) og 95\% öryggisbil (CI) fyrir virkt ferli á leikskólum og upplýsta og pjálfaða starfsmenn greint eftir menntunarstigi leikskólastjóra, menntun starfsmanns í eldhúsi, fjölda barna á leikskóla og fjölda starfsmanna á leikskóla. Hver skýribreyta var skoðuð ein og sér en einnig var framkvæmd fjölbreytugreining par sem leiðrétt var fyrir menntunarstigi leikskólastjóra og starfsmanns í eldhúsi, fjölda barna og fjölda starfsmanna á leikskólunum.

Krosstöflur voru notaðar til að bera stærð leikskóla, annars vegar eftir fjölda barna á leikskóla og hins vegar fjölda starfsmanna á leikskóla, saman við viðbragðsáætlun og upplýsta og pjálfaða starfsmenn. Einnig voru krosstöflur notaðar til að bera saman leikskóla með eða án bráðaofnæmis og hvort starfsfólk væri 
Tafla IV. Samband milli menntunar stjórnenda og hvort starfsmenn i leikskólum eru upplýstir og pjálfaðir í viðbrögðum við ofnæmiskasti barna.

\begin{tabular}{llll} 
& $N$ & Já $(\%)$ & OR \\
\hline Menntun leikskólastjóra & & & \\
\hline Grunnmenntun & 18 & $13(72)$ & - \\
\hline Viðbótardiplóma & 20 & $11(55)$ & $0,47(0,12-1,83)$ \\
\hline Framhaldsmenntun & 11 & $6(55)$ & $0,46(0,10-2,22)$ \\
\hline Menntun starfsmanns í eldhúsi & & & $0,56(0,11-2,95)$ \\
\hline Ómenntaður & 18 & $11(58)$ & - \\
\hline Menntaður & 30 & $19(66)$ & $1,10(0,33-3,66)$ \\
\hline
\end{tabular}

Leiðrétt fyrir fjölda barna á leikskóla og fjölda starfsfólks á leikskóla. OR = Odds ratio = gagnlíkindahlutfall.

upplýst og pjálfað og hvort pað pekki einkenni ofnæmiskasts. Notað var Fischers exact próf til að meta tölfræðilega marktækan mun.

\section{Niðurstöður}

Algengi fæðuofnæmis/-ópols

Allir leikskólarnir sem tóku pátt í rannsókninni, utan einn, voru með barn eða börn með fæðuofnæmi og/eða fæðuópol (98\%). Tæpur helmingur leikskólanna var með einstaklinga með bráðaofnæmi $(44,9 \%)$ og rúmlega helmingur með einstaklinga með fjölfæðuofnæmi (53,1\%) (tafla I). Metið út frá fjölda barna í leikskólunum ( $\mathrm{N}=4225)$ sem tóku pátt í rannsókninni var algengi fæðuofnæmis/-ópols 5,0\%, bráđaofnæmis 1,0\% og fjölfæðuofnæmis 1,1\% samkvæmt læknisvottorðum (tafla I).

Á mynd 1 sést hvaða fæðutegundir voru helst að valda ofnæmi eða ópoli. Mjólkurópol (2,3\%) var algengast en par á eftir mjólkurofnæmi (1,7\%), pví næst eggjaofnæmi (1,4\%) og hnetuofnæmi $(0,8 \%)$. Aðrir ofnæmisvaldar en peir koma fram á myndinni nefndu leikskólastjórar að væru til dæmis tómatar, sítrusávextir og jarðarber.

Mynd 2 sýnir súlurit yfir fjölda leikskóla með eitt eða fleiri börn með fæðuofnæmi/-ópol sumarið og haustið 2014. Eins og áður hefur komið fram var aðeins einn leikskóli án fæðuofnæmis/-ópols en flestir leikskólar voru með prjú börn með fæðuofnæmi/-ópol, eða 11 leikskólar. Hæst fór fjöldi barna með fæðuofnæmi/-ópol upp í fjórtán í einum leikskóla.

Verklag á leikskólum tengt börnum með fæðuofnæmi og/eða fæðuópol Flestir leikskólastjórar (90\%) svöruðu játandi aðspurðir hvort farið væri eftir ákveðnu verklagi pegar barn með fæðuofnæmi/-ópol innritast á leikskólann. Verklagið virtist pó ekki staðlað og svör voru mismunandi. Hér verða tekin dæmi um hvernig verklag fer í gang sem dregið var fram úr svörum leikskólastjóra par sem spurning var opin í spurningalistanum. Dæmi um verklag sem fer í gang er allt frá pví að eldhús sé látið vita af pví að barn með fæðuofnæmi sé að byrja á leikskólanum í að allir starfsmenn leikskólans hafi æft hvernig gefa skal adrenalínpenna og viti að hringja eigi í sjúkrabíl og láta foreldra vita ef barn með bráðaofnæmi fær ofnæmisviðbrögð. Algengast er pó að eldhús sé látið vita og mynd af barni sé hengd upp, ýmist á deild, í eldhúsi, á matarvagni eða á öllum pessum stöðum.
Meirihluti leikskóla (87,8\%) sagðist skrá og tilkynna til foreldris ef barn peirra fékk mat með ofnæmis-/ópolsvaka í.

Meirihluti leikskólanna (67,3\%) sagðist hengja upp spjöld með nafni barnsins og mynd af pví par sem tilgreint er hvaða fæðuofnæmi/-ópol er um að ræða. Aðrir leikskólar skrá upplýsingar um börn með fæðuofnæmi/-ópol til dæmis á töflu eða inni í eldhúsi.

Viðbragðsáxtlun í leikskólum og pjálfun starfsfólks vegna barna með fæðuofnæmil-ópol

Tafla II sýnir svör við eftirfarandi spurningunum: 1) Er til staðar viðbragðsáætlun sem fer í gang ef barn með fæðuofnæmi/-ópol fær mat með ofnæmisvaka í? og 2) Eru allir starfsmenn leikskólans upplýstir og pjálfaðir í pví hvernig bregðast skuli við ofnæmiskasti barns? Tæpur helmingur leikskóla (41\%) sagðist vera með viðbragðsáætlun sem færi í gang ef barn fengi fyrir slysni mat með ofnæmisvaka í en rúmur helmingur leikskólastjóra (61\%) sagði alla sína starfsmenn upplýsta og pjálfaða í að bregðast við ofnæmiskasti barns.

Niðurstöður aðhvarfsgreininga sýndu engin tengsl milli menntunarstigs leikskólastjóra og hvort til staðar væri viðbragðsáætlun í leikskólanum og hvort starfsmenn væru upplýstir og pjálfaðir í að bregðast við ofnæmiskasti barns (sjá töflu III og IV). Leiðrétting fyrir annars vegar fjölda barna í leikskóla og hins vegar fjölda starfsmanna hafði ekki áhrif á petta samband né marktækni.

Niðurstaða aðhvarfsgreiningar á hvort menntun starfsmanns í eldhúsi spái fyrir um hvort virkt ferli sé til staðar og hvort starfsmenn séu upplýstir og pjálfaðir sýndi heldur engin tengsl (tafla IV).

Pegar stærð leikskóla var skoðuð út frá fjölda barna og fjölda starfsmanna í tengslum við hvort virkt ferli væri til staðar, sem og hvort starfsmenn væru upplýstir og pjálfaðir í viðbrögðum við ofnæmislosti, mátti sjá að stærri leikskólar virtust frekar vera með virkt ferli og upplýsta og pjálfaða starfsmenn en sá munur var ekki marktækur (tafla V), hvort sem horft var til fjölda barna eða fjölda starfsmanna.

\section{Bráðaofnæmi}

Eins og áður sagði voru 50\% leikskóla með barn/börn með læknisvottorð par sem fram kom að viðkomandi væri með bráðaofnæmi. Allir peir leikskólar voru hnetulausir samanborið við 56\% leikskóla sem ekki voru með börn með bráðaofnæmi. 
Tafla V. Viðbragðsáætlun á leikskóla og upplýstir og pjálfaðir starfsmenn við ofnæmiskasti eftir fjölda barna og starfsmanna á leikskóla..

\begin{tabular}{|c|c|c|c|c|c|}
\hline & \multirow[b]{2}{*}{$\mathrm{N}$} & \multicolumn{2}{|c|}{ Virkt ferli } & \multicolumn{2}{|c|}{ Upplýstir og pjálfađir } \\
\hline & & Já (\%) & p-gildi ${ }^{1}$ & Já (\%) & p-gildi ${ }^{1}$ \\
\hline Fjöldi barna í leikskóla & & & 0,56 & & 0,38 \\
\hline Minni leikskóli (47-83 börn) & 23 & $8(35)$ & & $16(70)$ & \\
\hline Stærri leikskóli (84-172 börn) & 26 & $12(46)$ & & $14(54)$ & \\
\hline Fjöldi starfsmanna í leikskóla & & & 0,77 & & 0,24 \\
\hline Minni leikskóli (12-21 starfsmaður) & 24 & $9(38)$ & & $17(71)$ & \\
\hline Stærri leikskóli (22-42 starfsmenn) & 25 & $11(44)$ & & $13(52)$ & \\
\hline
\end{tabular}

${ }^{1}$ Fishers Exact próf.

Eins og sést í töflu VI voru um 64\% starfsmanna leikskóla með börn með bráđaofnæmi upplýstir um og pjálfaðir í pví hvernig skyldi bregðast við ofnæmiskasti barns. Hins vegar var rétt rúmur helmingur leikskóla (55\%) með börn með bráðaofnæmi sem sagði alla starfsmenn leikskólans pekkja einkenni ofnæmiskasts. Í peim leikskólum par sem greint var frá pví að ekki allir starfsmenn pekktu einkenni ofnæmiskasts, var algengast að leikskólastjóri, aðstoðarleikskólastjóri og starfsmenn deildar barns með bráðaofnæmi pekktu einkennin. Um 46\% leikskóla með börn með bráðaofnæmi voru með viðbragðsáætlun um hvernig bregðast skyldi við ef barn fengi fæðu með ofnæmisvaka í. Hins vegar sögðu stjórnendur 12 leikskóla barna með bráðaofnæmi (55\%) leikskólann vera með viðbragðsáætlun par sem æft væri hvernig bregðast skuli við ofnæmiskasti barns. Dæmi um viðbragðsáætlun pegar barn með bráðaofnæmi á í hlut:

- Viðbragðsáætlun hangir á viðkomandi deild/kaffistofu og/eða eldhúsi með upplýsingum um barnið, einkenni ofnæmiskasts og hvernig skuli bregðast við ef til ofnæmiskasts kemur.

- Allir starfsmenn kunna á adrenalínpennann og vita hvar hann er geymdur. Hringt er í 112 og foreldra.

- Æft er hvernig gefa skuli pennann.

- Viðbragðsáætlun er skráð og hlutverk hvers og eins starfsmanns er æft.

Í 14 (64\%) leikskólum barna með bráðaofnæmi var greint frá pví að adrenalínpenninn væri athugaður reglulega og passað að hafa hann aðgengilegan. Fimm leikskólar barna með bráðaofnæmi sögðu hann eingöngu vera á ábyrgð foreldra en prír leikskólar sem voru með einstaklinga með bráðaofnæmi svöruðu „,á ekki við“ við pessari spurningu.

\section{Tillögur að úrbótum - opin spurning til leikskólastjóranna}

Allir leikskólar ( $\mathrm{n}=22)$ sem voru með börn með bráðaofnæmi töldu að gagnlegt væri að fá sérfræðing til að halda fræðslu um fæðuofnæmi og fæðuópol fyrir starfsmenn leikskólans. Í heildina töldu $86 \%$ leikskóla pað vera gagnlegt en aðeins tveir leikskólar voru með reglubundna fræðslu sem hjúkrunarfræðingur veitti um málefni tengt fæðuofnæmi.

Fimmtán leikskólastjórar komu með tillögu að úrbótum og 6 peirra nefndu að peir vildu fá meira fé til matarkaupa fyrir börn með fæðuofnæmi/-ópol par sem fæði peirra væri oft dýrara. Pá
Tafla VI. Leikskólar með starfsfólk sem var upplýst og pjálfað i viðbrögðum við ofnæmiskasti barns og með starfsfólk sem pekkti einkenni ofnæmiskasts eftir pví hvort bráđaofnæmi er til staðar í leikskólanum.

\begin{tabular}{|c|c|c|c|c|c|}
\hline & \multirow[b]{2}{*}{$\mathrm{N}$} & \multicolumn{2}{|c|}{$\begin{array}{l}\text { Upplýstir og } \\
\text { pjálfaðir }\end{array}$} & \multicolumn{2}{|c|}{$\begin{array}{l}\text { Pekkja einkenni } \\
\text { ofnæmiskasts }\end{array}$} \\
\hline & & Já (\%) & p-gildi ${ }^{1}$ & Já (\%) & p-gildi ${ }^{1}$ \\
\hline & & & 0,78 & & 0,78 \\
\hline $\begin{array}{l}\text { Barn með bráđaofnæmi i } \\
\text { leikskóla* }\end{array}$ & 22 & $14(64)$ & & $12(55)$ & \\
\hline $\begin{array}{l}\text { Enginn með bráđaofnæmi í } \\
\text { leikskóla }\end{array}$ & 27 & $16(59)$ & & $13(48)$ & \\
\hline
\end{tabular}

${ }^{1}$ Fishers Exact próf.

* Samkvæmt læknisvottorði.

nefndu 5 leikskólastjórar að gott væri að hafa gagnagrunn par sem til dæmis væri hægt að sækja uppskriftir án ofnæmis/-ópolsvaka, fræðslu um ofnæmi/ópol og einn nefndi gátlista um hvernig best væri að bregðast við pegar barn fengi ofnæmis-/ópolsvaka. Tveir leikskólastjórar óskuðu eftir skýrari verklagsreglum um hversu lengi skyldi leyfa foreldrum að prófa breytt mataræði án vottorðs, hversu hart mætti ganga á eftir vottorðum og hvort vottorð mætti vera frá hvaða lækni sem er eða einungis frá ofnæmislækni.

Að lokum voru leikskólastjórar spurðir að pví hvort pað væri eitthvað sem peir vildu koma á framfæri og tengdist meirihluti athugasemdanna (n=7) ósk um að fá meiri og betri fræðslu og ráðgjöf.

\section{Umræða}

Rannsókn okkar sýndi að nær allir leikskólar í Reykjavík voru með börn með fæðuofnæmi eða fæðuópol og að um helmingur peirra var með börn með bráðaofnæmi. Algengi fæðuofnæmis og fæðuópols var 5\%, byggt á læknisvottorðum. Petta er aðeins hærra algengi en fyrri rannsóknir sýna að sé á Norðurlöndunum en okkar rannsókn byggir á að börnin hafi vottorð frá lækni um greiningu á fæðuofnæmi en aðrar rannsóknir byggja á húðprófum, blóðprófum og/eða tvíblindum polprófum. ${ }^{8,19}$ Alpjóðleg rannsókn sem kannaði algengi fæðuofnæmis með fæðupolsprófi í 89 löndum sýndi að algengi fæðuofnæmis meðal 0-5 ára barna var allt frá $1 \%$ í Tælandi til $10 \%$ í Ástralíu. ${ }^{20}$ Pegar fyrri rannsóknir eru bornar saman við okkar parf að hafa í huga að algengi fæðuofnæmis og fæðuópols er sjaldnast metið saman eins og gert var í pessari rann- 
sókn og pví erfiðara að bera hana saman við aðrar rannsóknir par sem einungis var kannað algengi fæðuofnæmis. ${ }^{6,8,19}$ Líklega má pví segja að algengi fæðuofnæmis í pessari rannsókn sé svipað pví sem sést í nágrannalöndum okkar. Tíðni fjölfæðuofnæmis í okkar rannsókn var 1,1\% og bráđaofnæmis $1 \%$. Fjölfæðuofnæmi í leikskólum í pessari rannsókn var ekki eins algengt og til að mynda í Danmörku, par sem pað hefur mælst 3,7\%. ${ }^{8}$

Mjólkurópol var algengast í leikskólunm en pví næst ofnæmi fyrir kúamjólk, eggjum og jarðhnetum. Færri (0,1\%) voru með greiningu vegna glútenópols borið saman við pað sem erlendar rannsóknir hafa sýnt. ${ }^{21-24}$ Íslensk rannsókn á 0-1 árs börnum sem var hluti af alpjóðlegu fæðuofnæmisrannsókninni EuroPrevall staðfesti fæðuofnæmi hjá 1,9\% barna með húðprófi, blóðprófi og tvíblindu polprófi. ${ }^{6}$ Í fyrrgreindri rannsókn var ekki kannað hvort börnin væru með mjólkurópol eða glútenópol sem einnig var til skoðunar í okkar rannsókn. Pá hefur dönsk rannsókn sýnt að algengi fæðuofnæmis er hæst í kringum priggja ára aldurinn en lækkar aftur við 6 ára aldur. ${ }^{8}$

Athyglisvert pykir að aðeins 41\% leikskólanna var með viðbragðsáætlun sem fer í gang ef barn fær mat með ofnæmisvaka í og pað hlutfall var litlu hærra (46\%) pegar leikskólar með börn með bráðaofnæmi voru skoðaðir sérstaklega. Einnig er pað alvarlegt að einungis um $61 \%$ leikskólanna greindi frá pví að allir starfsmenn væru upplýstir og pjálfaðir í hvernig ætti að bregðast við ofnæmiskasti barns. Petta hlutfall var svipað pegar einungis leikskólar með barn með bráðofnæmi voru skoðaðir, eða $64 \%$. Pó kom fram að í einungis 55\% leikskóla með barn með bráðaofnæmi pekktu allir starfsmenn einkenni ofnæmiskasts barns. Ekki var marktækur munur á leikskólum með og án bráđaofnæmis á pví hvort starfsfólk leikskólanna var upplýst og pjálfað í viðbrögðum við ofnæmiskasti. Рað er áhugavert út af fyrir sig par sem ætla mætti að leikskólar með barn með bráðaofnæmi væru líklegri til að vera með upplýsta og pjálfaða starfsmenn.

Pættir eins og menntun leikskólastjóra og starfsmanns í eldhúsi, stærð leikskóla, bæði eftir fjölda barna og fjölda starfsfólks, skiptu ekki máli í tengslum við hvort viðbragðsáætlun færi í gang ef barn með fæðuofnæmi/-ópol fengi mat með ofnæmisvaka. Раð sama mátti segja pegar áđurnefndir pættir voru skoðaðir í tengslum við hvort allt starfsfólk væri upplýst og pjálfað í pví hvernig bregðast ætti við ofnæmiskasti barns. Einnig var skoðað hvort pað væri munur á pekkingu starfsfólk á viðbrögðum við ofnæmiskasti barns eftir fjölda barna með læknisvottorð á hverjum leikskóla (0-3 á móti 4-14 vottorð) og ekki var marktækur munur á fjölda starfsmanna sem voru upplýstir háð fjölda læknisvottorða (gögn ekki sýnd). Rannsókn frá Tyrklandi par sem skoðað var hvort fyrir lægju viðbragðsáætlanir í leik- og grunnskólum til að koma í veg fyrir og bregðast við ofnæmislosti, sýndi að slíka viðbragðsáætlun skorti í 84\% tilvika. Einnig kom fram í rannsókninni að aðeins $3 \%$ kennara sögðust myndu nota adrenalínpenna ef barn fengi ofnæmislost. ${ }^{25}$

Einungis 14 (64\%) leikskólar barna með bráðaofnæmi athuguðu reglulega adrenalínpennann og gættu pess hafa hann aðgengilegan. Fimm stjórnendur leikskóla með barn með bráðaofnæmi sögðu að adrenalínpenninn væri eingöngu á ábyrgð foreldra og prír stjórnendur töldu að spurningin um adrenalínpennann ætti ekki við.

Rannsókn okkar sýnir að ýmsir innri pætti leikskólans, svo sem menntun og stærð, skipta ekki máli í tengslum við viðbragðsáætlun fyrir börn með fæðuofnæmi og fæðuópol. Pegar leikskólastjórarnir voru spurðir um hvers konar stuðning væri pörf á í pessum aðstæðum svöruðu margir að gagnlegt væri að fá sérfræðing til að halda fræðslu um fæðuofnæmi/-ópol fyrir starfsmenn leikskólans. Nokkrir leikskólastjórar nefndu að peir vildu meira fé til fæðukaupa fyrir börn með fæðuofnæmi en vitað er að sérfæði getur verið dýrara en almennt fæði. ${ }^{26}$ Einnig vildu leikskólastjórar til dæmis námskeið fyrir starfsfólk í eldhúsi og aðgengi að tengilið sem hefði frekari vitneskju um fæðuofnæmi og fæðuópol.

\section{Styrkleikar og takmarkanir}

Hátt svarhlutfall fékkst í rannsókninni (75\%) og spurningalistinn var ítarlegur og gaf góða innsýn í hvernig málefnum barna með fæðuofnæmi og/eða -ópol er háttað í leikskólum í Reykjavík.

Spurningalistinn sem notaður var í rannsókninni var ekki staðlaður heldur saminn af höfundum greinarinnar og gæti pað talist til takmarkana. Við úrvinnslu sást að sumar spurninganna hefðu getað verið betur orðaðar. Skipta hefði mátt spurningunni um hvort starfsfólk væri upplýst og pjálfað í að bregðast við ofnæmiskasti barns upp í tvær spurningar par sem spurt væri annars vegar hvort allt starfsfólk væri upplýst og hins vegar pjálfað í að bregðast við ofnæmiskasti barns. Pá skal tekið fram að svör við spurningum voru byggð á upplýsingum frá leikskólastjórum og gæti verið að pær upplýsingar endurspegli ekki endilega raunverulega pekkingu starfsfólks. Vissulega getur einnig verið um valskekkju аð ræða varðandi svörun spurningalistans, að peir leikskólar sem eru með barn með ofnæmi taki frekar pátt, sem hefur pá áhrif á útreikninga um algengi. Einnig gæti talist til takmarkana á athugun um algengi fæðuofnæmis/-ópols að mismunandi greiningar liggja að baki læknisvottorðum sem leikskólarnir fá, sem og að mismunandi ferli gætu verið á milli leikskólanna um hversu nýleg vottorðin purfa að vera og gæti pað einnig haft áhrif á niðurstöðurnar. Læknisvottorð vegna fæðuofnæmis er oftast byggt á niðurstöðum úr húð- og/eða blóðprófi. Hins vegar er yfirleitt ekki notast við læknisfræðilegt próf pegar mjólkurópol er staðfest af lækni heldur er greiningin byggð á frásögn foreldris. Gæti pað skekkt niðurstöðurnar og hækkað algengi mjólkurópols og pá í leiðinni algengi fæðuofnæmis og fæðuópols.

\section{Ályktun}

Rannsóknin sýndi að í nær öllum leikskólum í Reykjavík eru börn með fæðuofnæmi eða fæðuópol. Samkvæmt læknisvottorðum voru 5\% leikskólabarna með fæðuofnæmi og/eða fæðuópol í leikskólunum. Ljóst er að bæta parf fræðslu og áætlanir í tengslum við bráðaofnæmi svo að ekki sé vegið að heilsu barna með bráðaofnæmi innan veggja leikskólans. Einnig parf að samræma verklag milli leikskóla pegar barn með fæðuofnæmi eða fæðuópol innritast. Margir leikskólastjóranna í rannsókninni óskuðu eftir aðgengi að meiri fræðslu og sérfræðingi um pennan málaflokk. 


\section{Heimildir}

1. Steinke M, Fiocchi A, Kirchlechner V, Ballmer-Weber B, Brockow K, Hischenhuber C, et al. Perceived food allergy in children in 10 European nations. A randomised telephone survey. Int Arch Allergy Immunol 2007; 143: 290-5.

2. Venter C, Pereira B, Grundy J, Clayton $\mathrm{CB}$, Arshad $\mathrm{SH}$ Dean T. Prevalence of sensitization reported and objectively assessed food hypersensitivity amongst six-year-old children: a population-based study. Pediatr Allergy Immunol 2006; 17: 356-63.

3. Kavaliunas A, Surkiene G, Dubakiene R, Stukas $R$ Zagminas K, Saulyte J, et al. EuroPrevall survey on prevalence and pattern of self-reported adverse reactions to food and food allergies among primary schoolchildren in Vilnius, Lithuania. Medicina (Kaunas) 2012; 48: 265-71.

4. Kristinsdóttir $\mathrm{H}$, Jónasdóttir $\mathrm{S}$, Björnsson $\mathrm{S}$, Lúđvígsson $\mathrm{P}$. Beinkröm hjá barni. Læknablaðið 2011; 97: 477-80.

5. Dogruel D, Bingol G, Yilmaz M, Altintas DU. The ADAPAR Birth Cohort Study: Food Allergy Results at Five Years and New Insights. Int Arch Allergy Immunol 2016; 169: 57-61.

6. Kristinsdóttir H, Clausen M, Ragnarsdóttir HS, Halldórsdottir IH, McBride D, Beyer K, et al. Algeng fæðuofnæmis hjá íslenskum börnum á fyrsta ári. Læknablaðið 2011; 97: 11-8.

7. Sampson HA, Ho DG. Relationship between food-specific $\mathrm{IgE}$ concentrations and the risk of positive food challenges in children and adolescents. J Allergy Clin Immunol 1997; 100: 444-51.

8. Eller E, Kjaer HF, Host A, Andersen KE, Bindslev-Jensen C. Food allergy and food sensitization in early childhood: results from the DARC cohort. Allergy 2009; 64: 1023-9.

9. Dinakar C. Anaphylaxis in children: current understanding and key issues in diagnosis and treatment. Curr Allergy Asthma Rep 2012; 12: 641-9.
10. Braganza SC, Acworth JP, McKinnon DR, Peake JE, Brown AF. Paediatric emergency department anaphylaxis: different patterns from adults. Arch Dis Child 2006; 91: 159-63.

11. De Swert LF, Bullens D, Raes M, Dermaux AM. Anaphylaxis in referred pediatric patients: demographic and clinical features, triggers, and therapeutic approach. Eur J Pediatr 2008; 167: 1251-61.

12. Gaspar A, Santos N, Piedade S, Santa-Marta C, Pires G, Sampaio G, et al. One-year survey of paediatric anaphylaxis in an allergy department. Eur Ann Allergy Clin Immunol 2015; 47: 197-205.

13. de Silva IL, Mehr SS, Tey D, Tang ML. Paediatric anaphylaxis: a 5 year retrospective review. Allergy 2008; 63 : 1071-6.

14. Wang J, Sicherer SH. Section On A, Immunology Guidance on Completing a Written Allergy and Anaphylaxis Emergency Plan. Pediatrics 2017; 139 (3).

15. Deng Y, Misselwitz B, Dai N, Fox M. Lactose Intolerance in Adults: Biological Mechanism and Dietary Management. Nutrients 2015; 7: 8020-35.

16. Stamnaes J, Sollid LM. Celiac disease: Autoimmunity in response to food antigen. Semin Immunol 2015; 27: 343-52.

17. Le TM, Kummeling I, Dixon D, Barreales Tolosa L Ballmer-Weber B, Clausen M, et al. Low preparedness for food allergy as perceived by school staff: a EuroPrevall survey across Europe. J Allergy Clin Immunol Pract 2014; 2: 480-2.

18. Lýðheilsustöð. Handbók fyrir leikskólaeldhús. http:// reykjavik.is/sites/default/files/skjol_thjonustulysingar/ Handbok_leikskolaeldhus_april_2009.pdf - mars 2017.

19. Winberg A, West CE, Strinnholm A, Nordstrom L, Hedman L, Ronmark E. Assessment of Allergy to Milk, Egg, Cod, and Wheat in Swedish Schoolchildren: A Population Based Cohort Study. PLoS One 2015; 10: e0131804
20. Prescott SL, Pawankar R, Allen KJ, Campbell DE, Sinn J, Fiocchi A, et al. A global survey of changing patterns of food allergy burden in children. World Allergy Organ J 2013; 6: 21.

21. Dydensborg S, Toftedal P, Biaggi M, Lillevang ST, Hansen DG, Husby S. Increasing prevalence of coeliac disease in Denmark: a linkage study combining national registries. Acta Paediatr 2012; 101: 179-84

22. Karagiozoglou-Lampoudi T, Zellos A, Vlahavas G, Kafritsa Y, Roma E, Papadopoulou A, et al. Screening for coeliac disease in preschool Greek children: the feasibility study of a community-based project. Acta Paediatr 2013; 102: 749-54.

23. Maki M, Mustalahti K, Kokkonen J, Kulmala P, Haapalahti M, Karttunen T, et al. Prevalence of celiac disease among children in Finland. New Engl J Med 2003; 348: 2517-24.

24. Stordal K, Bakken IJ, Suren P, Stene LC. Epidemiology of coeliac disease and comorbidity in Norwegian children. J Pediatr Gastroenterol Nutr 2013; 57: 467-71.

25. Ozen A, Boran P, Torlak F, Karakoc-Aydiner E, Baris S, Karavus M, et al. School Board Policies on Prevention and Management of Anaphylaxis in Istanbul: Where Do We Stand? Balkan Med J 2016; 33: 539-42.

26. Protudjer JL, Jansson SA, Heibert Arnlind M, Bengtsson $U$, Kallstrom-Bengtsson I, Marklund B, et al. Household costs associated with objectively diagnosed allergy to staple foods in children and adolescents. J Allergy Clin Immunol Pract 2015; 3: 68-75.

\section{ENGLISH SUMMARY}

\section{Protocols Related to Food Allergies and Intolerances in Preschools in Reykjavik, Iceland}

Aðalheiður Rán Prastardóttir¹, Fríða Rún Pórðardóttir², Jóhanna Torfadóttir ${ }^{1,3}$

Introduction: The aim of the study was to explore prevalence of food allergies and intolerances among children in preschools in Reykjavik, Iceland. Also, to investigate how well preschools maintain a safe environment for children with food allergies.

Materials and methods: In 2014, a questionnaire designed specifically for this study, was sent to 65 preschools. Forty-nine participated (75\%) representing a total of 4225 children. Prevalence of food allergy and intolerance was determined based on medical certificates from physicians delivered to the preschools. Descriptive statistics were used to assess whether there were protocols related to food allergy, and if there was a difference between schools based on staff's education and number of children.

Results: The prevalence of documented food allergies/intolerances in children aged 2-6 years was 5\%, $1 \%$ had severe allergy and $1 \%$ had multiple food allergies. Lactose intolerance was most frequent $(2 \%)$, then milk allergy (2\%) and egg allergy (1\%). Only $41 \%$ preschools had a protocol that was activated if food with an allergen was accidentally given. Moreover, only $55 \%$ of preschools with children with severe allergy reported all of their staff to have knowledge of symptoms related to anaphylaxis and only $64 \%$ were trained to respond to an anaphylactic shock. The education of preschool principals, kitchen employees and number of children in preschool were not related to having an active protocol at site.

Conclusion: Prevalence of food allergy and intolerance was $5 \%$ in preschools in Reykjavik. Strategy for an active protocol related to food allergy was lacking in $59 \%$ of pre-schools. 